\title{
Architecting and Developing Big Data-Driven Innovation (DDI) in the Digital Economy
}

\author{
Saida Sultana, School of Business, University of Wollongong, Australia \\ Shahriar Akter, School of Business, University of Wollongong, Australia \\ (iD) https://orcid.org/0000-0002-2050-9985 \\ Elias Kyriazis, School of Business, University of Wollongong, Australia \\ Samuel Fosso Wamba, TBS Business School, France \\ iD https://orcid.org/0000-0002-1073-058X
}

\begin{abstract}
To revamp with new creative age characterized by ongoing digital transformation, more and more industries are capitalizing on digital innovation for their sustainable business growth. Drawing on a systematic literature review, thematic analysis, and using the theories of dynamic capabilities and market orientation, this research scrutinizes a systematic process for developing analytics-based data-driven innovation (DDI). Findings suggest a standardized seven-step process for DDI, including product conceptualization, data acquisition, data refinement, data storage and retrieval, distribution, presentation, and market feedback.
\end{abstract}

\section{KEYWORDS}

Big Data, Big Data-Driven Innovation (DDI), Big Data Analytics, Stages in DDI

\section{INTRODUCTION}

The world economy has transformed into a full-fledged digital economy in recent years led by datadriven innovation. A perfect storm of information and technological infrastructure growth has led to an expanded digital economy with data emerging as one of the most important strategic assets (Gopalkrishnan et al., 2012; Morabito, 2015; Tallon, 2013). Being at the edge of the experience era, big tech giants and other myriad companies now consider customer experience as a key differentiator with data considered a key competitive advantage (Kamioka \& Tapanainen, 2014; Rehan \& Mohammad Saud, 2020). Designing and developing data-driven innovations (DDI) is the way that these companies live, breathe, strive, and sustain their competitive advantage in such a vast competitive data-driven environment. Big data teamed with advanced analytic portfolios has boosted cutting-edge datadriven innovation in an unprecedented way (Debora Di et al., 2015; Groves et al., 2016; Lee et al., 2014; Yun et al., 2020). Traditionally agile data-driven corporations, e.g., Amazon, Google, Apple, and Facebook as well as emerging start-ups, are deriving incremental benefits and more durable competitive advantage from DDI. DDI is defined as any process, method, model, product or service that that create and capture value (Davenport \& Kudyba, 2016a). Using Netflix as an example, their personalized recommendation system captures data points on individual customer viewership and

\section{DOI: 10.4018/JGIM.2021050107}

This article, published as an Open Access article on April 16, 2021 in the gold Open Access journal, Journal of Global Information Management (JGIM) (converted to gold Open Access on January 1, 2021), is distributed under the terms of the Creative Commons Attribution License (http://creativecommons.org/licenses/by/4.0/) which permits unrestricted use, distribution, and production in any medium, provided the author of the original work and original publication source are properly credited. 
engagement on various TV shows and movies of more than 151 million subscribers. By implementing data analytics and algorithms, the company has developed its innovative recommendation platform that represents over $80 \%$ of the content streamed on the platform.

Such significant changes to business models are attributable to several factors which have functioned as capabilities for these global giants. These factors include advancement in information and communication technologies (ICT), growth of investment in big data and AI initiatives (Lu et al., 2018), strong data management and analytics capabilities (Kwon et al., 2014), strong data governance (Ladley, 2019), application of smart machines (Ransbotham \& Kiron, 2017), building a data culture accompanied with organizational alignment and cultural compliance (New Vantage Partners, 2017). Therefore, acknowledging the significance of big data and analytics in developing data-centric innovations, further investigation is required to support this important research field.

There has been a focus on numerous waves of data-driven innovations in recent years such as data-driven R\&D (Kayyali, 2013), data-intensive products (Zhan et al., 2016), data-driven processes, data-driven marketing (Erevelles et al., 2016), and data-driven organization. Data-driven researchers have also addressed dominant fields like, business intelligence (Chen et al., 2012), e-commerce (Akter \& Wamba, 2016; Joines \& Scherer, 2003), supply chain management (Sanders, 2014), smart city development (Ojo et al., 2015) and myriad of other domains. Acknowledging that DDI is in its infancy with limited theoretical and empirical research, there is nonetheless missing a comprehensive conceptualization based on a structured approach to the aforementioned data-driven initiatives. Such a gap has been identified by the extant research, which determines that the impending value of big data is yet to be revealed in the arena of new product innovation (LaValle et al., 2011; Davenport, 2013; Robert \& Candi, 2014; Tan et al., 2015).

Early research typically centred on developing traditional information products (Browning et al., 2002; Kim et al., 2006; Littler et al., 1995; Meyer \& Zack, 1996; Moenaert \& Souder, 1990; Nambisan, 2003; Von Hippel, 1998) with the absence of analytics. Studies on data product innovation in a structured fashion are still in its infantry, and therefore, the question regarding how companies can take innovation initiatives in a data-impelled culture remains unanswered (Biemans \& Langerak, 2015). Hence, the research question that has guided this study is:

RQ: What is the process of developing data-driven innovations (e.g., data products) in big data economy?

To answer this question, this study adopts a systematic literature review as a method based on similar applications applied in prior studies (Akter \& Wamba, 2016b). This study contributes to the literature in multiple ways. Firstly, it explores DDI and identifies the factors that lead to the sustainability of undertaking such innovation within the disruptive big data environment. Secondly, along with this exploration, this study presents the stages in the DDI model for developing data products that fit with the "time-to-market" phenomenon. For the successful design and development of data products, this research also recognizes various stakeholders' (e.g., data \& IT personnel, managers, marketing people, etc.) involvement throughout the process of DDI. The study has been structured in the following key sections. In section 2, we discuss the basic concepts (i.e., big data, big data analytics, and data-driven innovation). In section 3, we present some relevant studies conducted on DDI to show different approaches adopted by researchers. This section also sheds light on a list of challenges impending the initiatives for DDI. In Sections 4 and 5, we elucidate the methodological structure and findings of the systematic literature review. Finally, in the last section, theoretical and practical contributions are discussed. 


\section{LITERATURE REVIEW}

\subsection{Big Data}

With the unprecedented rise in e-commerce and advancement in digital technology, granular data is proliferating exponentially every second. Big data, therefore, is becoming one of the most inseparable words in all spheres of human life and the data-driven corporate mainstream.

Big data is the voluminous, diversified and more complex data set that can't be handled, processed and analysed by traditional data processing software (Akter \& Wamba, 2016b). According to Laney (2001), volume, variety, and velocity are the three scales used to define big data. The 'volume' refers to the massive amounts of data generated from various sources like web and social media platforms, transactions or activity data, sensor data, machine to machine data, biometric data, click-stream data, video data, and voice data. The 'velocity' is the speed at which data are being collected, administered and analyzed in real-time. The 'variety' refers to the diverse forms of data including structured, semistructured and unstructured collected in big data environment (Schroeck et al., 2012). In the same way, Dijcks (2012) characterizes big data with volume, velocity, variety, and added "value" as it implies the transactional, strategic and informational benefits of big data (Wamba et al., 2015; Wixom et al., 2013). However, considering the importance regarding the authenticity of data source, White (2012) included "veracity" to the list of big data V'S. The 'veracity' thus, represents the reliability or trustworthiness of different data sources from which data are being collected.

Schroeck et al. (2012) focused on market competition and defines big data as the blend of volume, variety, velocity, and veracity in order to accomplish a competitive advantage in today's digital market. Today with the aim of excelling data-driven competitors, more and more companies are infusing their resources in developing big data infrastructure that recognizes and exploits new market opportunities with the aid of big data analytics (Marshall et al., 2015). Kamioka and Tapanainen (2014) explore the connection between the utilization of big data and competitive advantage gained from such utilization in an organization. To outperform the competitors strategically, managers can utilize big data in assisting their decisions regarding appropriate new product development (Johnson et al., 2017). However, some researchers considered data as primary output or final goal of innovation process rather as a by-product (i.e., Trabucchi \& Buganza, 2019).

\subsection{Big Data Analytics (BDA)}

Since its beginning around the 1950s, the concept of analytics has no longer been considered a novel concept (Davenport, 2014). Big data analytics are the advanced analytical tools and methods applied on an extensive and diverse set of data to unearth hidden behavioral patterns, trends, relationships and other insights in order to reduce costs, increase efficiency and profits, identify new opportunities, and make happier customers. Bose (2009) described BDA as the "group of tools" used to extract, interpret information as well as predict the outcomes of decisions. Consistently, Davenport (2013b) denoted BDA as the quantitative analysis of big data in pursuance of making business decisions. Apart from assisting decision making, many firms also deploy analytics to find meaningful patterns in data in order to approach various business problems (Demirkan et al., 2015, pp.35). More recently, deploying AI-enabled analytics allows firms to predict customer purchase pattern in advance, anticipate credit fraud before it takes place, and place digital advertising to targeted customers in real-time (Davenport et al., 2019). Accordingly, firms should endeavor to combine big data and analytics in order to generate innovation and competitive advantage (Duan et al., 2020).

\subsection{Data-Driven Innovation (DDI) in Big Data Environment}

The process of unlocking the hidden value of data aiding further innovations in the realm of functional, operational, strategic and progressively entire business model is termed as data-driven innovation (DDI) (Davenport \& Kudyba, 2016). According to Stone and Wang (2014), utilization of any kind of data buttressing the innovation process with the aim of creating value is expounded as DDI. DDI 
renders innovative applications with strategic benefits derived from data analytics where performing analytics drive specific organizational performances and decision-making process. Google, Facebook Inc., Yahoo! Inc., and some others are the leading innovators building data products based on data and analytics. Facebook's, for instance, "People You May Know" feature shows people based on mutual friends, work, education information, and other factors. LinkedIn Corp. developed data products like "People You May Know", "Jobs You May Be Interested In" and "Groups You May Like" (Davenport, 2013a). Table 1 depicts the definitional aspects of data-driven innovation derived from distinct relevant studies.

Comprehending the significance of big data and analytics on new product performances, the recent studies continue to explore "the evidence that using big data intelligently will improve business performance" (McAfee et al., 2012, pp.63). In reality, upfront rivals are deploying "advanced analytics" or "discovery analytics" with a data deluge for greater understanding and planning of their marketing efforts (Akter \& Wamba, 2016b; Russom, 2011). Netflix's collaborative filtering algorithm to anticipate customer movie ratings (Chen et al., 2012), Google's use of users search behavior to target advertising (Hienz, 2014), and pursuit of big data to refine core search and ad-serving algorithms (Davenport \& Patil, 2012) are just a very few of those. Throughout this progression, DDI is being embedded as an innovative value propositions into an organization's core data products to make a complete market offering. For example, mobile apps ingrained with analytics are framing the "app economy" and have been considerably regarded as data products (OCED, "The App Economy" 2013). These creations and innovations are maneuvered to enhance customer experiences in many ways.

Table 1. Definitional Aspects of Data-driven Innovation

\begin{tabular}{|c|c|c|c|}
\hline Study & $\begin{array}{c}\text { Potential Research } \\
\text { Areas }\end{array}$ & Definition & Purpose \\
\hline $\begin{array}{l}\text { Bakshi, } \\
\text { (2012) }\end{array}$ & $\begin{array}{l}\text { Unstructured data } \\
\text { collection, storage and } \\
\text { analysis. }\end{array}$ & $\begin{array}{l}\text { Data-driven Innovation is } \\
\text { comprised of the acquisition, } \\
\text { processing, analyzing and } \\
\text { application of data in order to } \\
\text { excerpt the meaningful insights } \\
\text { from it. }\end{array}$ & $\begin{array}{l}\text { Proposing several techniques and } \\
\text { approaches for managing and analyzing } \\
\text { the growing number of unstructured data. }\end{array}$ \\
\hline $\begin{array}{l}\text { OECD, } \\
\text { (2014) } \\
\text { Rindfleisch } \\
\text { et al., } \\
\text { (2017) } \\
\text { Ylijoki, } \\
\text { (2019) }\end{array}$ & $\begin{array}{l}\text { The role of big data and } \\
\text { analytics for performing } \\
\text { growth (e.g., increased } \\
\text { productivity) and } \\
\text { well-being as well as } \\
\text { policy management for } \\
\text { maximizing value of } \\
\text { data-driven innovation. } \\
\text { The relationship between } \\
\text { "Innovation as Data" and } \\
\text { customer-lead digital } \\
\text { revolution; specifically } \\
\text { in terms of 3D printing. } \\
\text { The scope and } \\
\text { challenges of digital } \\
\text { transformation of } \\
\text { business driven by big } \\
\text { data. }\end{array}$ & $\begin{array}{l}\text { Data-centric process that } \\
\text { supports the combination of } \\
\text { both economic growth (i.e., } \\
\text { data-driven infrastructural } \\
\text { resources) and development } \\
\text { (i.e., expansion of multi-sided } \\
\text { market) is termed as data-driven } \\
\text { innovation. } \\
\text { Capturing, analyzing and } \\
\text { acting upon data generated by } \\
\text { consumers in order to strengthen } \\
\text { the way companies pursue for } \\
\text { innovating new products that } \\
\text { enhance customer experience. } \\
\text { DDI ensues when insights } \\
\text { derived from data, either } \\
\text { manually or automatically, lead } \\
\text { to improvements. }\end{array}$ & $\begin{array}{l}\text { Exemplifying the contributions of DDI } \\
\text { in economic growth as well as presenting } \\
\text { the risks associated with inappropriate } \\
\text { use of data and analytics. } \\
\text { Introducing the concept of "Innovation } \\
\text { as Data (IAD)" as well as suggesting } \\
\text { strategies for leveraging such an } \\
\text { innovative approach. } \\
\text { Exploring big data theories in order to } \\
\text { present novel knowledge and techniques } \\
\text { for innovating the conversion toward } \\
\text { data-driven businesses. }\end{array}$ \\
\hline
\end{tabular}




\subsection{Theoretical Foundations}

\subsubsection{Market Orientation}

Market orientation serves as a fundamental theory in the marketing literature for gaining competitive advantage. Gounaris et al., (2009) characterized market orientation as the amalgamation of gathered knowledge, skills and expertise helping a firm to bring it into line with recognizing and fulfilling market needs effectively. Market-oriented firms focus on developing and maintaining long term profitable relationship with customers by providing superior value to customers than their competitors. Being a critical resource for gaining sustainable competitive advantage (Hult \& Ketchen Jr, 2001), market orientation is considered as a significant knowledge-based asset that envisions future market possibilities (Hunt \& Morgan, 1995). Therefore, operating in a knowledge-based economy, datadriven firms can gain a considerable stance of market-sensing and customer-linking capabilities (Day, 1994) through developing a strong base for data-centric market intelligence through integrating market orientation. From a resource-based view (RBV), the adoption of market orientation also allows firms to combine resources that are scarce, invaluable and difficult to emulate by competitors (Amit \& Schoemaker, 1993; Barney, 1991). Thus, considering its appeal, a number of researchers have empirically proposed and examined the relationship between market orientation and new product performance and innovation (Atuahene-Gima, 1995; Calantone et al., 2002; Frishammar \& Åke Hörte, 2007; Ho et al., 2018; Hurley \& Hult, 1998; Kahn, 2001; Li et al., 2006; Lukas \& Ferrell, 2000; Narver et al., 2004; Wei et al., 2014; Wren et al., 2000; Wu et al., 2019). However, the theory of market orientation is rarely found in the literature of data-driven innovation (Yu et al., 2019). Addressing this shortcoming, theory of market orientation is conceptualized as an integral part of DDI development . It provides significantly greater explanatory power of how market-based knowledge and intelligence contribute to ideating data products as well as facilitating market feedback.

\subsubsection{Dynamic Capability}

The dynamic capability perspective has emerged as one of the most prominent theories in the field of product development and innovation (Deeds et al., 2000; Giniuniene \& Jurksiene, 2015; Marsh \& Stock, 2003; Verona, 1999; Winter, 2003; Zhou et al., 2019). This concept developed by Teece et al. (1997) demonstrates the capability of firms to attain the sustainable competitive advantage through capturing new opportunities and making expected outcomes out of those opportunities in an ever-changing business environment by deploying and rebuilding the complementary resources and assets. Gaining accumulative knowledge, skills and experiences are one of the central prerequisites for achieving competitive advantage (Barney, 1991) and the key resources that comprise knowledge stimulate innovation and advance new product development (Grant, 1996). As mentioned above, previous research has examined the accomplishment and implications of product innovation under dynamic environments (Lynch, 2019; Piening \& Salge, 2015; Prieto et al., 2009; Verona \& Ravasi, 2003) but no single attempt is evident in the area of how data-centric innovation can be attained and sustained where the industry is continuously disrupted by changing opportunities and challenges resulting from competitive forces and varying customer demands. Today the unprecedented volume, velocity, and variety of data and associated emerging technology have turned knowledge acquisition to revolve around the collection and administration big data. Drawing upon the dynamic capability literature highlights the data-driven firms' capacity for capturing and utilizing big data in order to transform it into dynamic data product innovation.

\subsubsection{Creativity Theory}

Under the creativity theory, the most widely accepted definition of creativity is the construction of novel and useful ideas that can successfully be implemented through innovation capabilities within an organization (Amabile, 1983, Amabile et al., 1996; Amabile, 1998). Earlier studies on new product development literature have confirmed two components of new product creativity: novelty 
and meaningfulness (Amabile, 1983; Sethi et al., 2001; Im \& Workman, 2004; Rubera et al., 2011). Meaningfulness indicates the degree of the appropriateness and usefulness of a new product offered to the market in relation to its competitors, whereas novelty represents the latitude that determines the uniqueness of a new product relative to its contenders (Amabile, 1983). Previous studies (Bakhshi et al., 2008; Goller \& Bessant, 2017; Maitanmi et al., 2019; Müller et al., 2009; Taalbi, 2017) proposed and evidenced creativity as one of the major drivers of innovation. For example, Hemment et al. (2017) introduced how art, creativity and public participation boost technology for smart city innovation. Cropley and Oppert (2018) explained how the elements of creativity drive organizational innovation. Creativity works as propelling force behind innovation (Benedict, 2018) and innovations produce novel knowledge and ideas, create access to new markets, enhance customer awareness and therefore improve the existing product offerings (Leonard-Barton, 1992; Gibson \& Birkinshaw, 2004). Thus, considering creativity theory, it can be theoretically generalized that if the firm possesses all capabilities (e.g., appropriate market mechanisms, skilled talents, and top management support) and resources (e.g., data and infrastructure) for creativity, it can successfully develop new innovative data products.

\section{DATA-DRIVEN INNOVATION MODELS}

Being enabled by the abilities stated earlier, data-driven enterprises strive to identify an appropriate and competitive data product to be developed. Cisco India, for instance, first assesses the market need followed by ensuring product portfolio and product-capability fit (building a product that is compatible with the subsidiary's capabilities). Developing a decision matrix and creating a working prototype through bootstrapping enables the company to turn its ideas into the ultimate data product in an emerging market (Jha et al., 2017). Nowadays, data monetization can also be a great source of competitive advantage for companies with hoards of data. According to Wixom and Ross (2017), companies can take three approaches to data monetization: "for improving internal business processes and decisions; for wrapping the offering around core products and services; and for selling information offering to the existing and new market" (pp. 1).

In recent times, involving customers in data-oriented innovations has been widespread. Zhan et al. (2018a) identified three different phases in customer-driven new product development (NPD) including generating ideas and concepts, designing and engineering individual products, and testing and launching new product or offering. Another customer-centric research project (Cooper, 2017a) found that using embedded customer feedback in developing an iterative series of "Build-Test-FeedbackRevise" to design and deliver new product innovation wasted no time at all. A study conducted by Jin et al. (2016) identified product attributes and sentiment divergences from big consumer opinion data and ends with exploiting the data in developing a framework for market-driven product design. Besides, considering its lifecycle, digital twin-driven product designing, manufacturing and services have also been investigated by the researchers (Tao et al., 2018). However, regardless of the types of data products, a framework regarding innovation-driven product development should provide an instrument to scientifically evaluate the success of product innovation (Zhang et al., 2004).

Research has also been conducted in the domain of data-driven service innovations. Examining and offering a standardized framework for service innovation is one of many focused areas where researchers have poured their efforts. After determining a list of opportunities and challenges regarding the service-oriented decision support system (DSS), Demirkan and Delen (2013) recommended a theoretical framework for DSS in the cloud. Demirkan and Spohrer (2014) developed a systematic framework for a data-driven cloud-enabled intelligent self-service systems to enhance the virtual shopping experience of customers in digital retail malls. To scrutinize how manufacturing service organizations in industry 4.0 transform in the impending big data environment, Lee et al. (2014) addressed the adaptive capabilities of those organizations toward smart predictive informatics and proposed the systematic framework including cyber-physical system and decision support system for long-run innovative services. Yu and Sangiorgi (2018) explored service design to associate value co- 
creation in reframing new service development (NSD) through holistic understanding and suggested a conceptual NSD model toward a customer/service-centric logic. Antons and Breidbach (2018) examined 69 distinct types of research in the domain of service design and innovation by introducing and manifesting the applicability of topic modeling and machine learning to provide an experimental contribution to service research. Like NPD, recent studies also explored NSD in terms of cocreating and innovating values through customer involvement (Edvardsson et al., 2012; Gemser and Perks, 2015; Gustafsson et al., 2012; Hoyer et al., 2010; Matthing et al., 2004). Table 2 represents several models proposed by innovation researchers for DDI.

\subsection{Challenges of Big Data-Driven Innovation}

With synthesizing enabling factors and multiple examples of big data-driven innovations, there is also growing tension regarding the challenges associated with the exploitation of big data. These challenges stretch from the degree of an organization's data literacy to the extent of privacy and security regarding the usage of data (Bose, 2009; Leelien Ken, 2009; Smith \& Shao, 2007). Challenges also apply in terms of stimulating the participation of other stakeholders in adopting and leveraging big-data-driven innovation (Hemerly, 2013). Nevertheless, strong data governance practice and data sharing, cultural norms and "differentiations" to narrow the strategic focus with the strongest advantage (Ransbotham \& Kiron, 2017) may minimize the associated risks and combat challenges. Alongside, providing the required training to data personnel and developing big data analytics competence focusing on "sophisticated technology, robust talent and analytics-driven management culture" (Akter \& Wamba, 2016a, pp.190) can streamline the existing management dilemma resting upon DDI.

Table 2. Recent Studies on Data-driven Innovation

\begin{tabular}{|c|c|c|}
\hline $\begin{array}{l}\text { DDI Research } \\
\text { Stream }\end{array}$ & $\begin{array}{l}\text { Relevant } \\
\text { Studies }\end{array}$ & Proposed Innovation Model \\
\hline $\begin{array}{l}\text { Market-driven New } \\
\text { Product Innovation } \\
\text { Data-driven } \\
\text { Accelerated } \\
\text { Innovation } \\
\text { Data-driven Product } \\
\text { innovation }\end{array}$ & $\begin{array}{l}\text { Butscher } \\
\text { and } \\
\text { Laker, } \\
(2000) \\
\text { Iqbal } \\
\text { et al., } \\
\text { (2010) } \\
\text { Cooper, } \\
\text { (2017b) } \\
\text { Zhan } \\
\text { et al., } \\
\text { (2017) } \\
\text { Zhan } \\
\text { et al., } \\
\text { (2018b) } \\
\text { Kusiak, } \\
\text { (2009) } \\
\text { Lin et al., } \\
\text { (2016) } \\
\text { Chien } \\
\text { et al., } \\
\text { (2016) } \\
\text { Tao et al., } \\
\text { (2019) }\end{array}$ & $\begin{array}{l}\text { Defining target customers; identifying competitive advantage; positioning new } \\
\text { products within target market; fine-tuning product design and pricing; market } \\
\text { simulations; and determining the target costs. } \\
\text { Qualitative and quantitative analysis; developing candidate solution; creating and } \\
\text { evaluating model; static validation; dynamic validation; and release solution. } \\
\text { Idea generation; scoping; building business case; new product development; testing } \\
\text { and validation; and full launch. } \\
\text { Accelerated innovation process; building close relations with customers; and } \\
\text { developing fast launch-and-improve ecosystem. } \\
\text { Autonomy; cross-functional teams; simultaneous processing; understanding } \\
\text { customers' needs; interaction with customers; customer co-creation; sharing } \\
\text { information and gathering feedback; network development; product launch and } \\
\text { improve; fast learning and improvement. } \\
\text { Prototype formulation; developing prototype alternative; evaluation of prototypes; } \\
\text { test configurations; and innovation score. } \\
\text { Understanding and defining the problem; identifying the niche for decision quality } \\
\text { improvement; forming the objective hierarchy and data collection; data preparation } \\
\text { and data mining; interpreting and evaluating results. } \\
\text { Defining the problem; preparing data; generating rules; and evaluating and } \\
\text { interpreting results. } \\
\text { Planning and task clarification; developing conceptual design; developing } \\
\text { embodiment design; preparing detail design; and virtual verification. }\end{array}$ \\
\hline
\end{tabular}




\section{METHODS}

To investigate the compatibility of the model for DDI as well as to prove how the stated model can include the historical combination of data and analytics, this research has adopted a systematic approach toward reviewing the literature based on similar applications in several prior studies, such as YurkoMauro et al. (2015) and Akter et al. (2019) in big data studies; Mikalef et al. (2018) and Thomas and Leiponen (2016) in big data analytics researches; Ngai and Wat (2002); Vaithianathan (2010); and Akter and Wamba (2016a) in e-commerce fields as well. A systematic literature review allows researchers to conduct a reliable amalgamation of evidence from relevant sources that successively leads them to accomplish a robust and comprehensive theoretical implications and conclusion on a given research question (Baumeister, 2013). Considering particular research objectives and purposes, the systematic approach consolidates and verifies appropriate studies in a coherent fashion (Greenhalgh et al., 2004; Sivarajah et al., 2017). Therefore, considering the subjective nature of the study, a systematic literature review deemed to be apposite and worthwhile in order to encapsulate a succinct empirical record on a structured approach for innovating data-driven products was conducted in a big data context.

This study generates the review process based on the following research questions: how analytics contribute to data-centric innovation? and what is the "standardized process" for designing and developing data products in data-driven firms? This question directed the literature review process precisely in determining appropriate theories, knowledge areas, academic and professional journal articles, web resources and bibliographic records. To practically answer the question, this study, therefore, reviewed related research conducted specifically on big data analytics and innovation, datadriven product development, data-oriented service innovation, data-driven innovation framework, customer-centric data product development, data-centric decision making, and big data value chain.

Literature related to new product development (NPD), data-driven innovation (DDI), technology innovation and service innovation was reviewed rigorously and exhaustively. As the research in DDI domain is still evolving, considering the published articles in between the year 2010 and 2019 seemed reasonable to represent an inclusive study of the literature. Relevant publications in the aforementioned literature were identified by using the search filaments comprised of several keywords. Although the preliminary focus was on "developing data-driven innovation", however, other fundamental phrases like "big data", "big data analytics", "big data-driven innovation" "big data-analytics driven innovation" "data products" were also used in narrowing down the field that fit the area of this research. Afterwards, to represent the entire scope of the study in terms of depicting how big data analytics enables data-driven innovation, these search strings were accompanied with "value of big data analytics" and "examples of analytics-driven data products".

In order to obtain the maximum number of scholarly articles and periodicals, several eminent research databases including Emerald (e.g., Journal of Knowledge Management), Wiley-Blackwell (e.g., Journal of Product Innovation Management), Scopus (Elsevier), and Science Direct (Elsevier) were explored. To do that, this study first executed a rigorous search on these databases using the keywords data-driven innovation with the terms phases/steps, design, value chain, time-to-market expectations etc. However, relevant publications from other databases were also extracted to develop arguments and support findings. While searching on the abovementioned databases, a total number of 103 articles appeared and later on, the articles those did not fit to the research area were dropped. Followed by Akter et al. (2019), search duplication was omitted, and selection criteria were specified, which led this research to select and scrutinize 63 most relevant publications. Finally, 22 articles were deemed to be directly connected to the development of data-centric innovations based on their explicit or implicit implications in terms of data-centric product innovation. Following the guidelines of Braun and Clarke (2006), this study performed a thematic analysis of the existing literature and came up with seven stages for data-centric innovation that conformed to the seven-step model for designing and developing analytics-based data products proposed by Davenport and Kudyba (2016). 


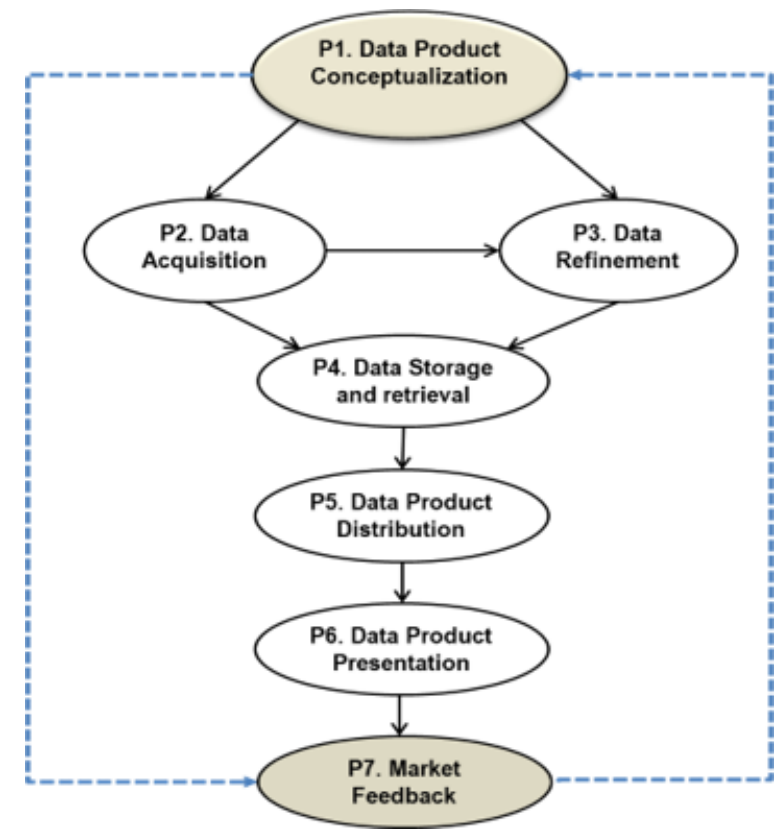

\section{FINDINGS ON DATA-DRIVEN INNOVATION PROCESS}

In the world of the traditional product innovation process, a various number of long time-consuming steps are taken in isolation that often ignores the market mechanism. In contrast, because of its unique nature like interactivity, continuity, and parallelism, the development of data-driven products is greatly influenced by how customers relate to companies and products resulting from the changing digital environment. Based on the thematic analysis, this study presents seven steps (see Figure 1) for architecting and developing data-driven innovation, which is discussed as follows.

\subsection{Step 1: Product Conceptualization}

Conceptualizing the market needs is the very first and probably the most important phase in the process of DDI. It sets the foundations as to whether the remaining steps of the development initiative would be efficient and whether the data product is going to be commercially successful. This process of conceptualization should take place before data acquisition and fine-tuned with a market feedback loop. In this stage, an organization must hypothesize the data product that satisfies the needs of the market, along with the available data sources required for that innovation. The product innovation process involves defining the product, investigating data, and establishing the framework for rapid prototyping (Davenport \& Kudyba 2016). According to Wixom and Ross (2017), once the key enablers (i.e., R\&D capacity, emerging market opportunity, and support of executive champions) for market innovation are positioned, as an example, Cisco India considers market need (what data product is to be produced), portfolio fit (how the product fits company's existing portfolio), and product-capability fit (how the product fits subsidiary's product-development capability) in terms of taking a decision about what data product to be developed.

At this stage, considering the product position defined by targeted consumers, developing a product architecture better facilitates the rigor of product innovation process where the market and technological opportunities, technological planning, and data platform opportunities influence architectural choice (Whitney, 2004). Therefore, with regard to customer-centered product innovation, an organization may 
embolden customer engagement, particularly in product definition and rapid prototyping processes. For example, Lenovo arranges a customer-based competition that includes online services, telematics and future PC online assistance systems (Bel, 2015). In another way, concrete focus on customers allows firms to discover novel ways to learn about and deliver new data products that better satisfy unique needs (Chen, 2015). After streamlining all these process components efficiently, the rest of the phases, for example, data acquisition, storage and retrieval, and even market feedback mechanisms can be transmitted with higher efficiency.

Proposition 1: Product conceptualization is the first step of the DDI process.

\subsection{Step 2: Data Acquisition}

After establishing a comprehensive and robust conceptualization model, the acquisition of data can be accomplished precisely. Due to the diversified and ubiquitous nature of data, a company's big data platform needs to attract all its data sources regardless of the data quality (Cohen et al., 2009). Therefore, in a big data environment, data can be acquired from completely unstructured (for example, tweets, blogs, social media data, and video data) to fully structured sources (e.g., retail transactions, customer demographic data, and sensor data). In addition, data-oriented technology allows firms to acquire more granular data on their end customers. Internet of Things (IoT), in this case, is reasonably identified as more capable than other new-age technologies such as Artificial Intelligence (AI), Machine Learning (ML) and Blockchain (Akter et al., 2020). By its sensing and monitoring capacities, IoT makes it possible to capture large-volumes of diversified data from billions of devices and objects connected on a network (Coetzee \& Eksteen, 2011). However, when fuelled by a massive amount of data, ML is to be considered as the second most important resource for data-driven innovation and growth (Hartmann \& Henkel, 2018). Thus, firms aspiring to achieve both efficiency and effectiveness should select the sources of data acquisition and aggregation as well as relevant technologies in such a fashion that coincide with the organization's business model and functionalities. In this regard, organizations should consider attending both within and outside of their system for the acquisition of such data (Dwoskin, 2015). Dynamically capable firms can develop the capacity to create, extend and customize their resource base that fit a particular business setting (Helfat et al., 2009). To respond to the data dynamism, companies must install such data processing pipelines that not only facilitates the acquisition of high-volume data but also ensures efficient data warehouse analysis tools for processing low-value data without losing any data throughout the process (Lyko et al., 2016). Thus, data acquisition should be adapted to the elaborative product architecture developed by the firm at the early stage of DDI process.

Proposition 2: Data acquisition is the second step of the DDI process.

\subsection{Step 3: Refinement}

To maximize the benefits of big data assets in deriving innovation, the implication of data refinement is crucial (Boiten, 2016). Composed of many distinctive sub-stages (Chen \& Udding, 1989), data refinement converts an abstract data model or conceptual blueprint into implementable data structure (Wirth, 2001) through refining unstructured and uncategorized raw data sets with the aim of upsurging the understanding of data, eliminating data volatility and redundancy, and developing a unified data resource and operation. At this abstract data innovation model or conceptual schema development phase, classes and relationships of all abstract entities or items are conscientiously classified and constructed in such a way that resembles organizations' real-life exercises and events. For instance, an Entity-Relationship Model (Bagui \& Bouressa, 2014; Pandey \& Pandey, 2019; Storey \& Song, 2017), a data modelling technique is used to delineate the variety of data to be stored and ensures 
efficient data management without sacrificing the quality of data in a database. A logical schema composition also functions in the same way where logical object related classes are defined.

Nowadays, through re-engineered and improved application of real-time machine learning, deep learning, and algorithm processing, data elements can better classify, coordinate, and epitomize customer profiles as well as spawn tremendous value for customers (Kiron et al., 2014). For example, using analytics, Bridgestone Americas Inc.'s new business model with data-driven innovations (data sharing between Bridgestone and automakers and software providers) can combine driver data (from odometer readings and other telematics data) and its own data to encourage car owners to visit repair stores in advance for tires and other services even before any problem takes place in their cars (Ransbotham \& Kiron, 2017). This, in turn, provides a new market opportunity to Bridgestone to create superior value for customers being learned about automobile performance and consumer behavior.

Proposition 3: Data refinement is the third step of the DDI process.

\subsection{Step 4: Storage and Retrieval}

In the emerging big data ecosystem, storage and retrieval offer the infrastructure for a data management platform (Koulouzis et al., 2019; O'Mara et al., 2016; Wang et al., 2018) that is designed to cope with and combine the variety, velocity, and volume of more unpolished and unpurified data and let all advanced storage analytics tools to run in the big data environment. Upon framing the system, understanding the business value of data innovation is crucial for defining the data storage strategy (Zillner et al., 2016) and planning regarding compliance need. Retrieval, in addition, ought to integrate leading-edge query and search processing competencies (Davenport \& Kudyba, 2016) that fit an organization's data-driven products and storage platform.

Being a powerful architecture, cloud integrates frameworks for parallel data processing to help users accessing cloud resources and deploying programs (Warneke \& Kao, 2009). Combining the computing utility model with a rich set of computations, infrastructures and storage, cloud services offer a highly attractive innovation environment (Gunarathne et al., 2013). Map reduction, for example, is a preferred scientific computation model (Xiao \& Xiao, 2014) that accelerates the processing of a large amount of data in the cloud environment and allows parallelization to a cluster of servers (O'Leary, 2013). With the advancements in analytics (for instance, HDFS-Hadoop Distributed File System), big data renditions a unified open-source environment (Tay, 2019) that simplifies the loading, extraction, transformation and processing of large and diverse sets of data.

Proposition 4: Data storage and retrieval platform is the fourth step of the DDI process.

\subsection{Step 5: Distribution}

Living in the age of ubiquitous data, the success of DDI largely depends on how a firm maintains its data structure and data product life-cycle (Kronsbein \& Mueller, 2019). According to planned obsolescence, data are governed for DDI with a shorter lifespan and are purged from archive immediately after exhaustion of value of those data. Examining the benefits and challenges of global business expansion, many firms are rebuilding their data infrastructure consists of a geo-distributed data platforms (Jeon et al, 2019; Vulimiri et al., 2015; Zhao et al, 2016) where data can be shared and updated on a near-real-time basis with fine-tuned control over data accessibility and availability. Based on the timing and frequency in distribution, the entire distribution model should facilitate rapid learning and quick resolution of issues through joint-problem solving.

However, with the evolution of the app-economy, incremental accessibility of mobile apps via smartphones, tablets and other devices has compelled data product innovators to overhaul their content configuration and design (Davenport \& Kudyba, 2016b). Simultaneously, the distribution of data products through clouds has let organizations garner the benefits of agility while reducing 
complexity and accelerating time to value. For instance, through implementing a real-time system called Distributor Connect, $P \& G$ manages inventory in real-time and keeps connected to its retailers through a globally synchronized data warehouse (Saldanha, 2019) that allows the company to manage commercial transactions in a completely automated fashion.

Proposition 5: Data product distribution is the fifth step of the DDI process.

\subsection{Step 6: Presentation}

Despite the richness of storage and distribution, presentation of data is crucial when a data product comes to correspond to distinct markets. An organization must combine a unique business and operational model with a certain set of analytic capabilities that support presenting and monetizing data to its stakeholders under intensive collaboration situations (Wixom \& Ross, 2017). The value of an information product is paid off from the context where it has been used (Meyer \& Zack, 1996) and likewise for the data products. An example can be State Street, one of the largest administrators of private equity assets, which collects data from 3000 private equity clients regarding their financial capital noted on the public stock exchange to create an aggregated data index. As this index represents the financial performance of those equity firms and possesses great value to the firm's targeted customers who need an exact representation of that index, State Street must incorporate analytics capabilities with a new division to present indexes in proper authenticity (Wixom \& Ross, 2017). Alongside, a unified data platform with proper data sharing across silos is critical for the success of data product presentation. For example, in the context of Deloitte, the unified data platform aides three other critical activities: data enrichment (a common set of services utilized to move data between systems), data persistence (the storage structure to maintain data within the unified data platform), and data consumption (the various services and systems of unified data platform that allow the organization to use its data).

Although the increased acceptance of the knowledge-based view (Nickerson \& Zenger, 2004) and exponential digitization is influencing the adoption level of analytics among adopters, the userinterface still should be considered in the diffusion of product innovation. Thus, when simple data products are appropriate for mass targeting, data products wrapped in cutting-edged analytics (realtime calculations generated through machine learning) will reward companies with creativity and differentiation (Davenport \& Kudyba, 2016b).

Proposition 6: Data product presentation is the sixth step of the DDI process.

\subsection{Step 7: Market Feedback}

Whether to create a new data product or, to re-engineer an existing one, harnessing a well-catalogued customer feedback platform empowers an innovator in terms of gaining customer insights (Hasson et al., 2019; Soroka et al., 2017; Wei et al., 2020), knowing competitor trend in the data-driven industry, and thus attaining competitive advantage over data rivals. This step is compatible with analytics-based data-driven innovation in a "lean startup" context that focuses on periodic refinement over time for continual innovation through minimizing the total time throughout the closed-loop process cycle.

For garnering unequivocal feedback from customers, listening to social media has been very worthwhile for many firms. For example, along with other capabilities, technologies including social media ratings abilities have enabled Uber empowering its customers through creating greater control of passengers over their rides (Grewal et al., 2019). While both passengers and drivers have the opportunity to rate each other based on their ride experiences, Uber uses this data to generate more value and satisfaction for customers. In addition to direct comments on social networks as one of the most common method, polling tools built in particular web pages (e.g., in Facebook) help in measuring user satisfaction with that page. Pedigree, a specialized pet food firm in Belgium, used an 
embedding survey in Facebook, allowing participants to finish the survey without opening another tab or leaving the page. Other enclosed on-site widgets like Beacon, can also be utilized to gather quick customer feedback. Apart from flash surveys, interactive blogs are being leveraged to appraise customer impressions regarding existing data products (Rajpathak \& Narsingpurkar, 2013; Zeidler, 2015). To gain unbiased feedback through simulating a real use of data product, bootstrapping usability test can be pursued. This test enables representative users to evaluate a product or service to provide their feedback regarding any usability problems.

Proposition 7: Market feedback is the final step of the DDI process.

\section{DISCUSSION}

\subsection{Theoretical Contributions}

Architecting and developing a data product based on analytical capabilities ensues in a circumstance which is incessantly disrupted by new technologies, change in market conditions and competition patterns. A data-driven firm's growth in a competitive environment depends on its dynamism and creativity in terms of fulfilling customers' varying needs (Im et al., 2013). Moreover, competition has further been intensified by the heavy investment in AI and advanced analytics by some companies. Considering this phenomenon, this study delivers three important theoretical contributions. First, it critically discourses how data products are completely different from those of mere information products through implicating the inevitable contribution of big data analytics in designing and developing data-driven innovations. Capabilities are firm-specific abilities that require considerable time and complex interactions among resources to be developed (Amit \& Schoemaker, 1993). Considering the dynamism and volatility changing and shaping the digital market, this research, therefore, expands the theory of DC through theoretically presenting a set of specific vital innovation capabilities in the context of data-driven product development. Characterized as knowledge-based, innovation performs a critical role in firm performance and competitive advantage (Kopanakis et al., 2016). Hence, this study extends MO theory by pertaining how digital firms can develop marketoriented innovative data products based on market-sensing and customer-linking capabilities in order to deliver superior value to customers and so to gain competitive advantages over rivals. Therefore, through drawing upon market orientation and dynamic capabilities, this research theoretically represents a set of unique steps and knowledge that firms require for DDI as well as reveals the urgency of integrating market mechanisms in the design and implementation of DDI to gain a sustainable competitive advantage in the industry. Finally, this study based on the creativity theory offers depth knowledge regarding how firms can embed creative thinking into their culture as well as what are the tools they can develop for applying creativity into data-centric environment. As a prerequisite of innovation (Nakata et al., 2018), this study expands the importance of creativity in terms of influencing and supporting organizational change beyond the traditional processes that fit to the time-to-market model of market-driven innovation. Assimilating all the mentioned findings into existing literature of NPD, this study offers the groundwork for building and expanding theories and guidelines for future research.

\subsection{Practical Contributions}

The questions guided this study hit directly to the practicality of suggesting a standardized model of DDI for all firms regardless of their operational and strategic differences. The ultimate findings of this study answer the research question through disclosing various phases practised by data people and managers in several data-driven firms with regard to designing real-time data products. Thus, this revelation has validated the feasibility of pursuing a standardized framework for DDI in real life and subsequently established guidance for other digital firms having involvement or intension to 
involve in DDI initiatives. Many data products have been developing in the last few years based on predictive modeling (see Aggarwal et al., 2018; Brynjolfsson \& McElheran, 2019; Heo et al., 2019; Jagannathan \& Udaykumar, 2020; Varghese, 2019; Wang et al., 2018 as examples), whether these are for weather forecasting or recommendation engines like Amazon's. An example can be Cloud Dataprep by Trifacta which is a data service, efficient for intelligent data preparation, including faster capturing, cleaning, and profiling of data (Novet, 2017) that are placed for further analysis. Companies wanting to make this sort of data service in the cloud can adapt the data product development model conferred in this study for capturing and analyzing all varieties of data in order to make the product or service more market-based. Another practical contribution of this study is to deliver a comprehensive understanding of the value of analytics in modelling and building data products. For example, this understanding will enable any data-driven firms to extract the hidden value from data for improved decision making through embedding visual analytics with services like 'Google Data Studio'. When these analytics are further coupled with business intelligence engines, the process of data investigation and visual interactivity grasp higher speed upon massive datasets. Taking these practical implications into consideration, this research will certainly aid managers and policymakers in terms of developing optimal strategies for data-driven innovation.

\subsection{Limitations}

The first limitation of this study originates from its qualitative nature. Ignoring any quantitative approach (i.e., survey) makes it challenging to provide empirical evidence throughout the research process. Furthermore, due to qualitative nature, this research maybe impacted by the researcher's personal thoughts, expertise, and experiences (Anderson, 2010). Dealing with a huge amount of qualitative data makes the analysis, interpretation, and presentation of findings difficult. Secondly, this paper is limited to offering environmental factors that influence data product development. Since the development of data-driven innovation is subject to various market dynamics (Cuzzocrea \& Tommasetti, 2017), depending on the category of industry an organization falls within, the type of data product a firm wants to develop as well as the cluster of customers the firm target to serve, this process may vary. Therefore, future studies can focus on incorporating various environmental factors for data-centric product development.

\subsection{Conclusion}

Establishing a comprehensive and robust data-driven innovation model would contribute to an emerging big data-driven environment. Through the accumulation of steps stretching from conceptualizing the product at the front loop and establishing market feedback instruments at the back loop, the study has uncovered the synchronization between customer feedback and its implications in product conceptualization in terms of developing distinct data product from distinct companies. Product-capability fit, based on these sort of findings, can be streamlined and re-engineered in accordance with the changes happening in consumer needs. Discoveries from this study will help organizations construct an effective decision-matrix in terms of choosing an appropriate approach o for rapid prototyping data products and innovations. Overall, this study contributes to enriching the theoretical and practical base for data-driven innovations. This study has also created a path for future researchers to test and update the implied model according to market dynamism and variations in data products within the same or diverse industries. 


\section{REFERENCES}

Aggarwal, C. C., Lingtao, C. A. O., Ng, T.H.M., Sathe, S., \& Turaga, D.S. (2018). Accurate temporal event predictive modeling. International Business Machines Corp, U.S. Patent Application 15/363,723.

Akter, S., Bandara, R., Hani, U., Wamba, S. F., Foropon, C., \& Papadopoulos, T. (2019). Analytics-based decision-making for service systems: A qualitative study and agenda for future research. International Journal of Information Management, 48, 85-95. doi:10.1016/j.ijinfomgt.2019.01.020

Akter, S., Michael, K., Uddin, M. R., McCarthy, G., \& Rahman, M. (2020). Transforming business using digital innovations: The application of AI, blockchain, cloud and data analytics. Annals of Operations Research, 1-33.

Akter, S., \& Wamba, S. F. (2016a). Big data analytics in E-commerce: A systematic review and agenda for future research. Electronic Markets, 26(2), 173-194. doi:10.1007/s12525-016-0219-0

Akter, S., \& Wamba, S. F. (2016b). Big data analytics in E-commerce: A systematic review and agenda for future research. Electronic Markets, 26(2), 1-22. doi:10.1007/s12525-016-0219-0

Amit, R., \& Schoemaker, P. J. (1993). Strategic assets and organizational rent. Strategic Management Journal, 14(1), 33-46. doi:10.1002/smj.4250140105

Anderson, C. (2010). Presenting and evaluating qualitative research. American Journal of Pharmaceutical Education, 74(8), 141. doi:10.5688/aj7408141 PMID:21179252

Antons, D., \& Breidbach, C. F. (2018). Big data, big insights? Advancing service innovation and design with machine learning. Journal of Service Research, 21(1), 17-39. doi:10.1177/1094670517738373

Atuahene-Gima, K. (1995). An exploratory analysis of the impact of market orientation on new product performance: a contingency approach. Journal of Product Innovation Management, 12, 275-293.

Bagui, S., \& Bouressa, J. (2014). Mapping rdf and rdf-schema to the entity relationship model. Journal of Emerging Trends in Computing and Information Sciences, 5(12), 953-961.

Bakhshi, H., McVittie, E., \& Simmie, J. (2008). Creating Innovation: Do the creative industries support innovation in the wider economy? Nesta London.

Bakshi, K. (2012). Considerations for big data: Architecture and approach. In 2012 IEEE Aerospace Conference. IEEE.

Barney, J. (1991). Firm resources and sustained competitive advantage. Journal of Management, 17(1), 99-120. doi:10.1177/014920639101700108

Bel, R. (2015). Innovating in China: Lessons for global companies. Global Business and Organizational Excellence, 34(2), 34-50. doi:10.1002/joe.21592

BenedictE. T. (2018). The Role of Creativity and Innovation in the Development of Entrepreneurship in South Asia: India as a Case Study. Available at SSRN 3297805.

Biemans, W., \& Langerak, F. (2015). More research priorities. Journal of Product Innovation Management, 32(1), 2-3. doi:10.1111/jpim.12255

Boiten, E. A. (2016). Big Data Refinement. arXiv preprint arXiv:1606.02017.

Bose, R. (2009). Advanced analytics: Opportunities and challenges. Industrial Management \& Data Systems, 109(2), 155-172. doi:10.1108/02635570910930073

Braun, V., \& Clarke, V. (2006). Using thematic analysis in psychology. Qualitative Research in Psychology, 3(2), 77-101. doi:10.1191/1478088706qp063oa

Browning, T. R., Deyst, J. J., Eppinger, S. D., \& Whitney, D. E. (2002). Adding value in product development by creating information and reducing risk. IEEE Transactions on Engineering Management, 49(4), 443-458. doi:10.1109/TEM.2002.806710

BrynjolfssonE.McElheranK. (2019). Data in Action: Data-Driven Decision Making and Predictive Analytics in US Manufacturing. Available at SSRN 3422397. 10.2139/ssrn.3422397 
Butscher, S. A., \& Laker, M. (2000). Market-driven product development. Marketing Management, 9, 48.

Calantone, R. J., Cavusgil, S. T., \& Zhao, Y. (2002). Learning orientation, firm innovation capability, and firm performance. Industrial Marketing Management, 31(6), 515-524. doi:10.1016/S0019-8501(01)00203-6

Chen, H., Chiang, R. H., \& Storey, V. C. (2012). Business intelligence and analytics: From big data to big impact. Management Information Systems Quarterly, 36(4), 36. doi:10.2307/41703503

Chen, W., \& Udding, J. T. (1989). Towards a calculus of data refinement. In International Conference on Mathematics of Program Construction (pp. 197-218). Springer. doi:10.1007/3-540-51305-1_11

Chen, Y.-J. (2015). The role of reward systems in product innovations: An examination of new product development projects. Project Management Journal, 46(3), 36-48. doi:10.1002/pmj.21499

Chien, C.-F., Kerh, R., Lin, K.-Y., \& Yu, A. P.-I. (2016). Data-driven innovation to capture user-experience product design: An empirical study for notebook visual aesthetics design. Computers \& Industrial Engineering, 99, 162-173. doi:10.1016/j.cie.2016.07.006

Cohen, J., Dolan, B., Dunlap, M., Hellerstein, J. M., \& Welton, C. (2009). MAD skills: New analysis practices for big data. Proceedings of the VLDB Endowment International Conference on Very Large Data Bases, 2(2), 1481-1492. doi:10.14778/1687553.1687576

Cooper, R. G. (2017a). Idea-to-Launch Gating Systems: Better, Faster, and More Agile: Leading firms are rethinking and reinventing their idea-to-launch gating systems, adding elements of Agile to traditional StageGate structures to add flexibility and speed while retaining structure. Research Technology Management, 60(1), 48-52. doi:10.1080/08956308.2017.1255057

Cooper, R. G. (2017b). Winning at new products: Creating value through innovation. New York, NY: Basic Books.

Cropley, D. H., \& Oppert, M. L. (2018). The fuzzy front-end? How creativity drives organizational innovation. In Individual Creativity in the Workplace. Elsevier.

Cuzzocrea, A., Loia, V., \& Tommasetti, A. (2017). June. Big-data-driven innovation for enterprises: innovative big value paradigms for next-generation digital ecosystems. In Proceedings of the 7th International Conference on Web Intelligence, Mining and Semantics (pp. 1-5). Academic Press.

Davenport, T. H. (2013a). Analytics 3.0. Harvard Business Review, 91(12), 64.

Davenport, T. H. (2013b). The Analytics Advantage. We're just getting started. Deloitte Analytics.

Davenport, T. H. (2014). Big data at work: dispelling the myths, uncovering the opportunities. Harvard Business Review Press. doi:10.15358/9783800648153

Davenport, T. H., \& Kudyba, S. (2016). Designing and Developing Analytics-Based Data Products. MIT Sloan Management Review, 58, 83-89.

Davenport, T. H., \& Patil, D. (2012). Data scientist. Harvard Business Review, 90, 70-76. PMID:23074866

Day, G. S. (1994). The capabilities of market-driven organizations. Journal of Marketing, 58(4), 37-52. doi:10.1177/002224299405800404

Debora Di, C., Francisco, J. S.-A., \& Madjid, T. (2015). Technology Development through Knowledge Assimilation and Innovation: A European Perspective. Journal of Global Information Management, 23(2), 48-93. doi:10.4018/JGIM.2015040103

Deeds, D. L., DeCarolis, D., \& Coombs, J. (2000). Dynamic capabilities and new product development in high technology ventures: An empirical analysis of new biotechnology firms. Journal of Business Venturing, 15(3), 211-229. doi:10.1016/S0883-9026(98)00013-5

Demirkan, H., Bess, C., Spohrer, J., Rayes, A., Allen, D., \& Moghaddam, Y. (2015). Innovations with Smart Service Systems: Analytics, Big Data, Cognitive Assistance, and the Internet of Everything. CAIS, $37,35$.

Demirkan, H., \& Delen, D. (2013). Leveraging the capabilities of service-oriented decision support systems: Putting analytics and big data in cloud. Decision Support Systems, 55(1), 412-421. doi:10.1016/j.dss.2012.05.048 
Demirkan, H., \& Spohrer, J. (2014). Developing a framework to improve virtual shopping in digital malls with intelligent self-serdevice systems. Journal of Retailing and Consumer Services, 21(5), 860-868. doi:10.1016/j. jretconser.2014.02.012

Dijcks, J.-P. (2012). Oracle: Big data for the enterprise. Oracle white paper, 16.

Dwoskin, E. (2015). Startup Factual Knows Your Commute, and Much More. . . Wall Street Journal.

Edvardsson, B., Kristensson, P., Magnusson, P., \& Sundström, E. (2012). Customer integration within service development-A review of methods and an analysis of insitu and exsitu contributions. Technovation, 32(7-8), 419-429. doi:10.1016/j.technovation.2011.04.006

Frishammar, J., \& Åke Hörte, S. (2007). The role of market orientation and entrepreneurial orientation for new product development performance in manufacturing firms. Technology Analysis and Strategic Management, 19(6), 765-788. doi:10.1080/09537320701711231

Gemser, G., \& Perks, H. (2015). Co-creation with customers: An evolving innovation research field. Journal of Product Innovation Management, 32(5), 660-665. doi:10.1111/jpim.12279

Giniuniene, J., \& Jurksiene, L. (2015). Dynamic capabilities, innovation and organizational learning: Interrelations and impact on firm performance. Procedia: Social and Behavioral Sciences, 213, 985-991. doi:10.1016/j. sbspro.2015.11.515

Goller, I., \& Bessant, J. (2017). Creativity for innovation management. Routledge. doi:10.4324/9781315630588

Gopalkrishnan, V., Steier, D., Lewis, H., \& Guszcza, J. (2012). Big data, big business: bridging the gap. In Proceedings of the 1st International Workshop on Big Data, Streams and Heterogeneous Source Mining: Algorithms, Systems, Programming Models and Applications (pp. 7-11). doi:10.1145/2351316.2351318

Grant, R. M. (1996). Prospering in dynamically-competitive environments: Organizational capability as knowledge integration. Organization Science, 7(4), 375-387. doi:10.1287/orsc.7.4.375

Greenhalgh, T., Robert, G., Macfarlane, F., Bate, P., \& Kyriakidou, O. (2004). Diffusion of innovations in service organizations: Systematic review and recommendations. The Milbank Quarterly, 82(4), 581-629. doi:10.1111/j.0887-378X.2004.00325.x PMID:15595944

Groves, P., Kayyali, B., Knott, D., \& Kuiken, S.V. (2016). The 'big data' revolution in healthcare: Accelerating value and innovation. Academic Press.

Gunarathne, T., Zhang, B., Wu, T.-L., \& Qiu, J. (2013). Scalable parallel computing on clouds using Twister4Azure iterative MapReduce. Future Generation Computer Systems, 29(4), 1035-1048. doi:10.1016/j.future.2012.05.027

Gustafsson, A., Kristensson, P., \& Witell, L. (2012). Customer co-creation in service innovation: A matter of communication? Journal of Service Management, 23(3), 311-327. doi:10.1108/09564231211248426

Hasson, S. G., Piorkowski, J., \& McCulloh, I. (2019). August. Social media as a main source of customer feedback: alternative to customer satisfaction surveys. In Proceedings of the 2019 IEEE/ACM International Conference on Advances in Social Networks Analysis and Mining (pp. 829-832). doi:10.1145/3341161.3345642

Helfat, C. E., Finkelstein, S., Mitchell, W., Peteraf, M., Singh, H., Teece, D., \& Winter, S. G. (2009). Dynamic capabilities: Understanding strategic change in organizations. John Wiley \& Sons.

Hemerly, J. (2013). Public policy considerations for data-driven innovation. Computer, 46(6), 25-31. doi:10.1109/ MC.2013.186

Hemment, D., Bletcher, J., \& Coulson, S. (2017). Art, creativity and civic participation in IoT and Smart City innovation through 'Open Prototyping'. Creativity World Forum 2017: Creativity Cities and Neighborhoods of Opportunity.

Heo, J., Lim, H., Yun, S. B., Ju, S., Park, S., \& Lee, R. (2019). March. Descriptive and Predictive Modeling of Student Achievement, Satisfaction, and Mental Health for Data-Driven Smart Connected Campus Life Service. In Proceedings of the 9th International Conference on Learning Analytics \& Knowledge (pp. 531-538). doi:10.1145/3303772.3303792

Hienz, J. (2014). The future of data-driven innovation. US Chamber of Commerce Foundation. 
Ho, K. L. P., Nguyen, C. N., Adhikari, R., Miles, M. P., \& Bonney, L. (2018). Exploring market orientation, innovation, and financial performance in agricultural value chains in emerging economies. Journal of Innovation \& Knowledge, 3(3), 154-163. doi:10.1016/j.jik.2017.03.008

Hoyer, W. D., Chandy, R., Dorotic, M., Krafft, M., \& Singh, S. S. (2010). Consumer cocreation in new product development. Journal of Service Research, 13(3), 283-296. doi:10.1177/1094670510375604

Hult, G. T. M., \& Ketchen, D. J. Jr. (2001). Does market orientation matter?: A test of the relationship between positional advantage and performance. Strategic Management Journal, 22(9), 899-906. doi:10.1002/smj.197

Hunt, S. D., \& Morgan, R. M. (1995). The comparative advantage theory of competition. Journal of Marketing, 59(2), 1-15. doi:10.1177/002224299505900201

Hurley, R. F., \& Hult, G. T. M. (1998). Innovation, market orientation, and organizational learning: An integration and empirical examination. Journal of Marketing, 62(3), 42-54. doi:10.1177/002224299806200303

Im, S., Montoya, M. M., \& Workman, J. P. Jr. (2013). Antecedents and consequences of creativity in product innovation teams. Journal of Product Innovation Management, 30(1), 170-185. doi:10.1111/j.15405885.2012.00887.x

Iqbal, M. A., Zaidi, A. M., \& Murtaza, S. (2010). A new requirement prioritization model for market driven products using analytical hierarchical process. In Proceeding of the International Conference on Data Storage and Data Engineering. IEEE. doi:10.1109/DSDE.2010.49

Jagannathan, J., \& Udaykumar, U. (2020). Predictive Modeling for Improving Healthcare Using IoT: Role of Predictive Models in Healthcare Using IoT. In Incorporating the Internet of Things in Healthcare Applications and Wearable Devices (pp. 243-254). IGI Global.

Jeon, J., Kim, J., Kim, J., Kim, K., Mohaisen, A., \& Kim, J. K. (2019). Privacy-Preserving Deep Learning Computation for Geo-Distributed Medical Big-Data Platforms. In 49th Annual IEEE/IFIP International Conference on Dependable Systems and Networks-Supplemental Volume (DSN-S) (pp. 3-4). IEEE. doi:10.1109/ DSN-S.2019.00007

Jha, R., Jbara, A.-A., Qazvinian, V., \& Radev, D. R. (2017). NLP-driven citation analysis for scientometrics. Natural Language Engineering, 23(1), 93-130. doi:10.1017/S1351324915000443

Jin, J., Liu, Y., Ji, P., \& Liu, H. (2016). Understanding big consumer opinion data for market-driven product design. International Journal of Production Research, 54(10), 3019-3041. doi:10.1080/00207543.2016.1154208

Johnson, J. S., Friend, S. B., \& Lee, H. S. (2017). Big data facilitation, utilization, and monetization: Exploring the $3 \mathrm{Vs}$ in a new product development process. Journal of Product Innovation Management, 34(5), 640-658. doi:10.1111/jpim.12397

Kahn, K. B. (2001). Market orientation, interdepartmental integration, and product development performance. Journal of Product Innovation Management. An International Publication Of The Product Development \& Management Association, 18, 314-323.

Kamioka, T., \& Tapanainen, T. (2014). Organizational Use of Big Data and Competitive Advantage-Exploration of Antecedents. PACIS.

Kim, K.-Y., Manley, D. G., \& Yang, H. (2006). Ontology-based assembly design and information sharing for collaborative product development. Computer Aided Design, 38(12), 1233-1250. doi:10.1016/j.cad.2006.08.004

Kiron, D., Prentice, P. K., \& Ferguson, R. B. (2014). The analytics mandate. MIT Sloan Management Review, 55, 1.

Koulouzis, S., Martin, P., Zhou, H., Hu, Y., Wang, J., Carval, T., Grenier, B., Heikkinen, J., de Laat, C., \& Zhao, Z. (2019). Time-critical data management in clouds: Challenges and a Dynamic Real-Time Infrastructure Planner (DRIP) solution. Concurrency and Computation, 32(16), e5269. doi:10.1002/cpe.5269

Kronsbein, T., \& Mueller, R. (2019). Data Thinking: A Canvas for Data-Driven Ideation Workshops. Proceedings of the 52nd Hawaii International Conference on System Sciences. doi:10.24251/HICSS.2019.069

Kusiak, A. (2009). Innovation: A data-driven approach. International Journal of Production Economics, 122(1), 440-448. doi:10.1016/j.ijpe.2009.06.025 
Kwon, O., Lee, N., \& Shin, B. (2014). Data quality management, data usage experience and acquisition intention of big data analytics. International Journal of Information Management, 34(3), 387-394. doi:10.1016/j. ijinfomgt.2014.02.002

Ladley, J. (2019). Data governance: How to design, deploy, and sustain an effective data governance program. Academic Press.

Laney, D. (2001). 3D data management: Controlling data volume, velocity and variety. META group research note 6,1 .

Lee, J., Kao, H. A., \& Yang, S. (2014). Service innovation and smart analytics for industry 4.0 and big data environment. Procedia CIRP, 16(1), 3-8. doi:10.1016/j.procir.2014.02.001

Leelien Ken, H. (2009). The Contingent Role of Innovation between IT Management Sophistication and Strategic Alignment. Journal of Global Information Management, 17(2), 60-92. doi:10.4018/jgim.2009040103

Li, Y., Liu, Y., \& Zhao, Y. (2006). The role of market and entrepreneurship orientation and internal control in the new product development activities of Chinese firms. Industrial Marketing Management, 35(3), 336-347. doi:10.1016/j.indmarman.2005.05.016

Lin, K.-Y., Chien, C.-F., \& Kerh, R. (2016). UNISON framework of data-driven innovation for extracting user experience of product design of wearable devices. Computers \& Industrial Engineering, 99, 487-502. doi:10.1016/j.cie.2016.05.023

Littler, D., Leverick, F., \& Bruce, M. (1995). Factors affecting the process of collaborative product development: A study of UK manufacturers of information and communications technology products. Journal of Product Innovation Management: An International Publication Of The Product Development \& Management Association, 12(1), 16-32. doi:10.1111/1540-5885.1210016

Lu, H., Li, Y., Chen, M., Kim, H., \& Serikawa, S. (2018). Brain intelligence: Go beyond artificial intelligence. Mobile Networks and Applications, 23(2), 368-375. doi:10.1007/s11036-017-0932-8

Lukas, B. A., \& Ferrell, O. C. (2000). The effect of market orientation on product innovation. Journal of the Academy of Marketing Science, 28(2), 239-247. doi:10.1177/0092070300282005

Lyko, K., Nitzschke, M., \& Ngomo, A.-C. N. (2016). Big data acquisition, New Horizons for a Data-Driven Economy. Springer.

Lynch, R. (2019). Towards an innovation link between dynamic capabilities and sustainability strategy: Options for emerging market companies. International Journal of Innovation and Technology Management, 16(04), 1940003. doi:10.1142/S0219877019400030

Maitanmi, S. O., Ogunlere, S. O., \& Adio, A. K. (2019). Shaping ICT Infrastructure Through Creativity and Innovation. Indian Journal of Science and Technology, 12(41), 41. doi:10.17485/ijst/2019/v12i41/147513

Marsh, S. J., \& Stock, G. N. (2003). Building dynamic capabilities in new product development through intertemporal integration. Journal of Product Innovation Management, 20(2), 136-148. doi:10.1111/15405885.2002006

Marshall, A., Mueck, S., \& Shockley, R. (2015). How leading organizations use big data and analytics to innovate. Strategy and Leadership, 43(5), 32-39. doi:10.1108/SL-06-2015-0054

Matthing, J., Sandén, B., \& Edvardsson, B. (2004). New service development: Learning from and with customers. International Journal of Service Industry Management, 15(5), 479-498. doi:10.1108/09564230410564948

McAfee, A., Brynjolfsson, E., Davenport, T. H., Patil, D., \& Barton, D. (2012). Big data: The management revolution. Harvard Business Review, 90, 60-68. PMID:23074865

Meyer, M., \& Zack, M. H. (1996). Te Design and Development of Information Products. Sloan Management Review, 37, 43-59.

Mikalef, P., Pappas, I. O., Krogstie, J., \& Giannakos, M. (2018). Big data analytics capabilities: A systematic literature review and research agenda. Information Systems and e-Business Management, 16(3), 547-578. doi:10.1007/s10257-017-0362-y 
Moenaert, R. K., \& Souder, W. E. (1990). An information transfer model for integrating marketing and R\&D personnel in new product development projects. Journal Of Product Innovation Management: An International Publication Of The Product Development \& Management Association, 7(2), 91-107. doi:10.1111/15405885.720091

Morabito, V. (2015). Big data and analytics. Strategic and organisational impacts. Academic Press.

Müller, K., Rammer, C., \& Trüby, J. (2009). The role of creative industries in industrial innovation. Innovation, 11(2), 148-168. doi:10.5172/impp.11.2.148

Nambisan, S. (2003). Information systems as a reference discipline for new product development. Management Information Systems Quarterly, 27(1), 1-18. doi:10.2307/30036517

Narver, J. C., Slater, S. F., \& MacLachlan, D. L. (2004). Responsive and proactive market orientation and new-product success. Journal of Product Innovation Management, 21(5), 334-347. doi:10.1111/j.07376782.2004.00086.x

Ngai, E. W., \& Wat, F. (2002). A literature review and classification of electronic commerce research. Information \& Management, 39(5), 415-429. doi:10.1016/S0378-7206(01)00107-0

Nickerson, J. A., \& Zenger, T. R. (2004). A knowledge-based theory of the firm-The problem-solving perspective. Organization Science, 15(6), 617-632. doi:10.1287/orsc.1040.0093

Novet, J. (2017). Google launches Cloud Dataprep, an embedded version of Trifacta. Venture Beat, (March), 9.

O’Leary, D. E. (2013). Exploiting big data from mobile device sensor-based apps: Challenges and benefits. MIS Quarterly Executive, 12.

O’Mara, J., Meredig, B., \& Michel, K. (2016). Materials data infrastructure: A case study of the citrination platform to examine data import, storage, and access. Journal of Marketing, 68(8), 2031-2034.

PandeyA. K.PandeyR. (2019). Data Modeling and Performance Analysis Approach of Big Data. Available at SSRN 3356806. 10.2139/ssrn.3356806

Piening, E. P., \& Salge, T. O. (2015). Understanding the antecedents, contingencies, and performance implications of process innovation: A dynamic capabilities perspective. Journal of Product Innovation Management, 32(1), 80-97. doi:10.1111/jpim.12225

Prieto, I. M., Revilla, E., \& Rodríguez-Prado, B. (2009). Building dynamic capabilities in product development: How do contextual antecedents matter? Scandinavian Journal of Management, 25(3), 313-326. doi:10.1016/j. scaman.2009.05.005

Rajpathak, T., \& Narsingpurkar, A. (2013). Managing knowledge from Big Data analytics in product development. White Paper, Tata Consultancy Services.

Ransbotham, S., \& Kiron, D. (2017). Analytics as a source of business innovation. MIT Sloan Management Review, 58.

Rehan, I., \& Mohammad Saud, K. (2020). Social Media Big Data Analytics for Demand Forecasting: Development and Case Implementation of an Innovative Framework. Journal of Global Information Management, 28(1), 103-120. doi:10.4018/JGIM.2020010106

Rindfleisch, A., O'Hern, M., \& Sachdev, V. (2017). The digital revolution, 3D printing, and innovation as data. Journal of Product Innovation Management, 34(5), 681-690. doi:10.1111/jpim.12402

Russom, P. (2011). Big data analytics. TDWI best practices report, fourth quarter 19, 1-34.

Saldanha, T. (2019). Why Digital Transformations Fail: The Surprising Disciplines of How to Take Off and Stay Ahead. Berrett-Koehler Publishers.

Schroeck, M., Shockley, R., Smart, J., Romero-Morales, D., \& Tufano, P. (2012). Analytics: The real-world use of big data. IBM Global Business Service, 12, 1-20.

Sivarajah, U., Kamal, M. M., Irani, Z., \& Weerakkody, V. (2017). Critical analysis of Big Data challenges and analytical methods. Journal of Business Research, 70, 263-286. doi:10.1016/j.jbusres.2016.08.001 
Smith, R., \& Shao, J. (2007). Privacy and e-commerce: A consumer-centric perspective. Electronic Commerce Research, 7(2), 89-116. doi:10.1007/s10660-007-9002-9

Soroka, A., Liu, Y., Han, L., \& Haleem, M. S. (2017). Big data driven customer insights for SMEs in redistributed manufacturing. Procedia CIRP, 63, 692-697. doi:10.1016/j.procir.2017.03.319

Stone, D., \& Wang, R. (2014). Deciding with data-How data-driven innovation is fuelling Australia's economic growth. Pricewaterhouse Coopers. PWC.

Storey, V. C., \& Song, I. Y. (2017). Big data technologies and management: What conceptual modeling can do. Data \& Knowledge Engineering, 108, 50-67. doi:10.1016/j.datak.2017.01.001

Taalbi, J. (2017). What drives innovation? Evidence from economic history. Research Policy, 46(8), 1437-1453. doi:10.1016/j.respol.2017.06.007

Tallon, P. P. (2013). Corporate governance of big data: Perspectives on value, risk, and cost. Computer, 46(6), 32-38. doi:10.1109/MC.2013.155

Tao, F., Cheng, J., Qi, Q., Zhang, M., Zhang, H., \& Sui, F. (2018). Digital twin-driven product design, manufacturing and service with big data. International Journal of Advanced Manufacturing Technology, 94(912), 3563-3576. doi:10.1007/s00170-017-0233-1

Tao, F., Sui, F., Liu, A., Qi, Q., Zhang, M., Song, B., Guo, Z., Lu, S. C.-Y., \& Nee, A. (2019). Digital twindriven product design framework. International Journal of Production Research, 57(12), 3935-3953. doi:10. 1080/00207543.2018.1443229

Tay, C. (2019). Envisioning the Win in a Hadoop Environment. Academic Press.

Thomas, L. D., \& Leiponen, A. (2016). Big data commercialization. IEEE Engineering Management Review, 44, 74-90. doi:10.1109/EMR.2016.2568798

Vaithianathan, S. (2010). A review of e-commerce literature on India and research agenda for the future. Electronic Commerce Research, 10(1), 83-97. doi:10.1007/s10660-010-9046-0

Varghese, S., Stahlhut, W. A., Gahnoog, M. A., Dintenfass, K., Vuong, M. N., \& Wadley, C. D. (2019). Predictive Modeling for Event Delivery Based on Real-Time Data. U.S. Patent Application 15/726,895.

Verona, G. (1999). A resource-based view of product development. Academy of Management Review, 24(1), 132-142. doi:10.5465/amr.1999.1580445

Verona, G., \& Ravasi, D. (2003). Unbundling dynamic capabilities: An exploratory study of continuous product innovation. Industrial and Corporate Change, 12(3), 577-606. doi:10.1093/icc/12.3.577

Von Hippel, E. (1998). Economics of product development by users: The impact of "sticky" local information. Management Science, 44(5), 629-644. doi:10.1287/mnsc.44.5.629

Vulimiri, A., Curino, C., Godfrey, B., Karanasos, K., \& Varghese, G. (2015). WANalytics: Analytics for a GeoDistributed Data-Intensive World. CIDR.

Wamba, S. F., Akter, S., Edwards, A., Chopin, G., \& Gnanzou, D. J. I. J. P. E. (2015). How 'big data' can make big impact: Findings from a systematic review and a longitudinal case study. International Journal of Production Economics, 165, 234-246. doi:10.1016/j.ijpe.2014.12.031

Wang, H., Suo, T., Wu, X., Zhang, Y., Wang, C., Yu, H., \& Li, Z. (2018). Near infrared spectroscopy based monitoring of extraction processes of raw material with the help of dynamic predictive modeling. Spectrochimica Acta. Part A: Molecular and Biomolecular Spectroscopy, 192, 222-227. doi:10.1016/j.saa.2017.11.023 PMID:29149693

Wang, L., Ma, Y., Yan, J., Chang, V., \& Zomaya, A. Y. (2018). pipsCloud: High performance cloud computing for remote sensing big data management and processing. Future Generation Computer Systems, 78, 353-368. doi:10.1016/j.future.2016.06.009

Warneke, D., \& Kao, O. (2009, November). Nephele: efficient parallel data processing in the cloud. In Proceedings of the 2nd workshop on many-task computing on grids and supercomputers (pp. 1-10). doi:10.1145/1646468.1646476 
Wei, Q., Shi, X., Li, Q., \& Chen, G. (2020). Enhancing Customer Satisfaction Analysis with a Machine Learning Approach: From a Perspective of Matching Customer Comment and Agent Note. Proceedings of the 53rd Hawaii International Conference on System Sciences. doi:10.24251/HICSS.2020.178

Wei, Z., Zhao, J., \& Zhang, C. (2014). Organizational ambidexterity, market orientation, and firm performance. Journal of Engineering and Technology Management, 33, 134-153. doi:10.1016/j.jengtecman.2014.06.001

White, M. (2012). Digital workplaces: Vision and reality. Business Information Review, 29(4), 205-214. doi: $10.1177 / 0266382112470412$

Whitney, D.E. (2004). Mechanical assemblies: their design, manufacture, and role in product development. Oxford Series on Advanced Manufacturing.

Winter, S. G. (2003). Understanding dynamic capabilities. Strategic Management Journal, 24(10), 991-995. doi:10.1002/smj.318

Wirth, N. (2001). Program development by stepwise refinement. In Pioneers and Their Contributions to Software Engineering (pp. 545-569). Springer. doi:10.1007/978-3-642-48354-7_23

Wixom, B. H., \& Ross, J. W. (2017). How to monetize your data. MIT Sloan Management Review, 58.

Wixom, B. H., Yen, B., \& Relich, M. (2013). Maximizing value from business analytics. MIS Quarterly Executive, 12(2).

Wren, B. M., Souder, W. E., \& Berkowitz, D. (2000). Market orientation and new product development in global industrial firms. Industrial Marketing Management, 29(6), 601-611. doi:10.1016/S0019-8501(00)00120-6

Wu, J., Ma, Z., \& Liu, Z. (2019). The moderated mediating effect of international diversification, technological capability, and market orientation on emerging market firms' new product performance. Journal of Business Research, 99, 524-533. doi:10.1016/j.jbusres.2018.03.025

Xiao, Z., \& Xiao, Y. (2014). Achieving accountable MapReduce in cloud computing. Future Generation Computer Systems, 30, 1-13. doi:10.1016/j.future.2013.07.001

Ylijoki, O. (2019). Big Data-Towards Data-driven Business. Academic Press.

Yu, E., \& Sangiorgi, D. (2018). Service design as an approach to implement the value cocreation perspective in new service development. Journal of Service Research, 21(1), 40-58. doi:10.1177/1094670517709356

Yu, L., Yao, C., Yuan, L., \& Christopher, P. H. (2019). Market Orientation, Alliance Governance, and Innovation. Journal of Global Information Management, 27(1), 1-18. doi:10.4018/JGIM.2019010101

Yun, C., Lian, D., \& Weiyong, Z. (2020). Effect of User Involvement in Supply Chain Cloud Innovation: A Game Theoretical Model and Analysis. Journal of Global Information Management, 28, 23-38.

Yurko-Mauro, K., Alexander, D. D., \& Van Elswyk, M. E. (2015). Docosahexaenoic acid and adult memory: A systematic review and meta-analysis. PLoS One, 10(3), e0120391. doi:10.1371/journal.pone.0120391 PMID:25786262

Zeidler, B. (2015). 6 ways to extract Customer Insights From Social Conversations. Academic Press.

Zhan, Y., Tan, K. H., Ji, G., Chung, L., \& Tseng, M. (2017). A big data framework for facilitating product innovation processes. Business Process Management Journal, 23(3), 518-536. doi:10.1108/BPMJ-11-2015-0157

Zhan, Y., Tan, K. H., Li, Y., \& Tse, Y. K. (2018a). Unlocking the power of big data in new product development. Annals of Operations Research, 270(1-2), 577-595. doi:10.1007/s10479-016-2379-x

Zhan, Y., Tan, K. H., \& Perrons, R. K. (2018b). A proposed framework for accelerated innovation in data-driven environments: Evidence and emerging trends from China. Industrial Management \& Data Systems, 118(6), 1266-1286. doi:10.1108/IMDS-11-2017-0542

Zhang, Q., Lim, J.-S., \& Cao, M. (2004). Innovation-driven learning in new product development: A conceptual model. Industrial Management \& Data Systems, 104(3), 252-261. doi:10.1108/02635570410525799 
Zhao, Y., Huang, Z., Liu, W., Peng, J., \& Zhang, Q. (2016). A combinatorial double auction based resource allocation mechanism with multiple rounds for geo-distributed data centers. In 2016 IEEE International Conference on Communications (ICC). IEEE. doi:10.1109/ICC.2016.7510724

Zhou, S. S., Zhou, A. J., Feng, J., \& Jiang, S. (2019). Dynamic capabilities and organizational performance: The mediating role of innovation. Journal of Management \& Organization, 25(5), 731-747. doi:10.1017/jmo.2017.20

Zillner, S., Becker, T., Munné, R., Hussain, K., Rusitschka, S., Lippell, H., Curry, E., \& Ojo, A. (2016). Big datadriven innovation in industrial sectors. In New Horizons for a Data-Driven Economy (pp. 169-178). Springer. doi:10.1007/978-3-319-21569-3_9

Saida Sultana has been working as a Senior Lecturer in Uttara University, Bangladesh since 2015. She is currently pursuing MPhil in marketing in University of Wollongong (UOW), Australia with International Postgraduate Tuition Award. She accomplished her MBA and BBA (with distinction) in marketing from East West University, Bangladesh. She teaches business, marketing and HRM. She also worked as Graduate Teaching Assistant during pursuing her MBA. Before coming to teaching, Saida worked for several multinational organizations as well. Her primary research interests include consumer behaviour. Specifically, she is interested in big data and data-driven innovation.

Shahriar Akter is an Associate Professor in the Sydney Business School at the University of Wollongong, Australia. Shahriar received his doctorate from University of New South Wales (UNSW) Business School. As part of his doctoral program, Shahriar received his methodological training from Oxford Internet Institute, University of Oxford. He has published in the leading international journals including Information \& Management, Journal of Business Research, International Journal of Production Economics, International Journal of Production Research, International Journal of Operations and Production Management, Electronic Markets, Journal of the American Society for Information Science \& Technology, Behaviour \& IT, Communication of AIS, Journal of Selected Areas in Communication etc. Shahriar's research interests include service systems evaluation, big data and business analytics, and complex modelling using PLS.

Elias Kyriazis received his PhD in Marketing from the University of Wollongong where he is the longest serving member of the Marketing Discipline. His teaching and research areas have focused on innovation and marketing's cross-functional relationships with other key functional areas. With the emergence of big data and digital marketing as dynamic capabilities, his current research focus is on marketing's role in innovation and key strategic decisionmaking in organizations. He has published in R\&D Management, European Journal of Marketing and the International Journal of Innovation Management.

Samuel Fosso Wamba is a Professor at Toulouse Business School. He earned his Ph.D. in industrial engineering at the Polytechnic School of Montreal, Canada. His research interests include IT adoption and use, artificial intelligence, business analytics, big data, and open data. He has published papers in: Academy of Management Journal, European Journal of Information Systems, Information Systems Frontiers, International Journal of Production Economics, International Journal of Production Research, Journal of Business Research, Technology Forecasting and Social Change, and Production Planning \& Control. He is the head of the Artificial Intelligence \& Business Analytics Cluster of Toulouse Business School, France. 